\title{
Occupational Stress in Landing Platform Dock (LPD) Project Workers of PT. PAL Indonesia
}

\author{
Stres Kerja pada Pekerja Project Landing Platform Dock (LPD) PT. PAL \\ Indonesia
}

\author{
Nunung Dwi Radanny, Sho'im Hidayat \\ Department of Occupational Safety and Health, Faculty of Public Health Universitas Airlangga \\ Campus C Mulyorejo, Surabaya, East Java Indonesia 60115
}

\begin{abstract}
Introduction: Occupational stress is a condition in which the body responds physiologically, psychologically, and also behaviorally towards stressor. It can have negative effect on the workers and the workplace. The objective of this research is to study occupational stress and factors related to it in workers at Landing Platform Dock (LPD) project, especially Merchant Ship Division of PT PAL Indonesia. Methods: This research is an observational descriptive research. The subjects of the research are all the 32 workers of the project. The variables are occupational stress, individual characteristic, and work environment. Data was analyzed to discover the correlation between variables using contingency coefficient and Spearman correlation. Results: The total 32 workers, $21.8 \%$ suffer from mild stress, $68.8 \%$ suffer from moderate stress, and $9.4 \%$ suffer from severe stress. Statistical test results show that there is a moderate correlation between level of education (coefficient -0.446), workload (coefficient 0.533), and relationship at work (coefficient 0.494) toward occupational stress. Meanwhile, personality factor (coefficient 0.334) and marital status (coefficient 0.231) have a weak impact on occupational stress. Furthermore, age (coefficient 0.146) has an extremely weak impact on occupational stress. Conclusion: Factors that highly contributes to occupational stress are education level, workload, and relationship at work. Other factors such as age, personality type, and marital status only have a small correlation with occupational stress in these workers.
\end{abstract}

Keywords: individual characteristic, occupational stress, work environment

\begin{abstract}
ABSTRAK
Pendahuluan: Stres kerja adalah suatu kondisi atau respon tubuh seseorang berupa respon fisiologis, psikologis maupun perilaku terhadap adanya stressor. Stres kerja dapat berdampak negatif pada diri pekerja maupun perusahaan tempat bekerja. Tujuan dari penelitian ini adalah mempelajari stres kerja dan faktor yang berhubungan pada pekerja project Landing Platform Dock (LPD) di Divisi Kapal Niaga PT PAL Indonesia (Persero). Metode: Penelitian ini merupakan penelitian observasional deskriptif. Subyek penelitian merupakan total populasi sebesar 32 pekerja. Variabel penelitian ini yaitu stres kerja, faktor karakteristik individu dan faktor lingkungan pekerjaan. Analisa data untuk mengetahui kuat hubungan antar variabel menggunakan koefisien kontingensi dan korelasi spearman. Hasil: Dari total 32 pekerja, 21,8\% mengalami stres ringan, 68,8\% mengalami stres sedang, dan 9,4\% mengalami stres berat. Hasil uji statistik menunjukkan terdapat hubungan sedang pada faktor tingkat pendidikan (koefisien -0,446), beban kerja (koefisien 0,533), dan hubungan dalam pekerjaan (koefisien 0,494) dengan stres kerja. Faktor Tipe kepribadian (koefisien0,334) dan status pernikahan (koefisien 0,231) memiliki hubungan lemah dengan stres kerja, sedangkan faktor umur (koefisien 0,146) memiliki hubungan yang sangat lemah dengan stres kerja. Simpulan: Faktor yang berperan besar dalam terjadinya stress kerja yaitu tingkat pendidikan, beban kerja, dan hubungan dalam pekerjaan karena memiliki hubungan yang sedang dengan stres kerja. Faktor lain seperti umur, tipe kepribadian, dan status pernikahan kurang berperan dalam terjadinya stres kerja karena memiliki hubungan yang lemah dengan terjadinya stress kerja pada pekerja.
\end{abstract}

Kata kunci: karakteristik individu, lingkungan pekerjaan, stres ker

Author for Correspondence:

Nunung Dwi Radanny

E-mail: nunungdwiss@gmail.com 


\section{INTRODUCTION}

Occupational stress is a condition of individual subjective immersion that can take place in individual interaction and workplace, which can threat and burden a person psychologically, physiologically, and behaviorally (Wijono, 2012). In other words, occupational stress is a condition in which individual body responds physiology, psychology, and behaviorally toward stressors (the causes of stress). Stressors might be originated from within the individuals or their workplace.

Occupational stress takes place in all workplaces either abroad or in Indonesia. Furthermore, in England, there were 526,000 cases related to occupational stress, depression or anxiety in 2016 with a prevalence rate of 1,610 cases per 100,000 workers. There are 236,000 new cases with a prevalence rate of 720 cases per 100,000 workers. The number of loss related to missing working days caused by occupational stress is 12.5 million per day, approximately 23.8 missing days per cases (Health and Safety Executive, 2017). Meanwhile, in Indonesia, there is no data yet regarding to occupational stress prevalence rate. This is because there is not enough awareness on occupational stress, and there is no particular institution that specifically study occupational stress experienced by Indonesian workers.

However, there have been some researches that measure occupational stress level in some companies in Indonesia. A study conducted on 68 workers in spinning division of PT Sinar Pantja Djaja Semarang shows that 41 workers $(60.29 \%)$ experienced high occupational stress, 12 workers (17.65\%) experienced extremely high occupational stress, 11 workers (16.18) experienced moderate occupational stress, and 4 workers (5.88\%) experienced low occupational stress (Failasufa, Pawenang and Indarjo, 2014).

Moreover, workers at Sentra Industri Gamelan Wirun Sukoharjo show similar condition. From the total of 48 workers, 28 of them $(58.33 \%)$ experienced high occupational stress, 16 of them $(33.33 \%)$ experienced moderate category, 2 of them $(4.17 \%)$ experienced extremely high category, and the other $2(4.17 \%)$ experienced low occupational stress (Panengah, 2012). Based on researches above, it can be concluded that occupational stress in Indonesia is high. Therefore, there is an urgency to undertake a research on occupational stress among. Such research will be useful in formulating preventive and corrective measures and avoiding undesirable effect either for workers or for companies.

Stress is a form of individual's response against sources or causes of stress called stressor. It can lead to positive or negative implication, depending on the individual's response to the stressor. Controllable stressor leads to positive implication called eustress, which acts as a motivation to enhance performance. On the contrary, uncontrollable stressor leads to negative implication called distress, which becomes source of pressure during working. These stressors can be an intrinsic factor at work, individual role in organization, career development, relationship at work, structural and organizational atmosphere, demands outside of work, and individual characteristics (Munandar, 2001).

Individual characteristic such as age, education level, personality type, and marital status are the factors that correlate to occupational stress. According to Irkhami (2015), the older individuals are, the more prone they will be to occupational stress. Individuals with higher education possess maturity traits in thinking, so they can manage stress better. Personality type A correlates with occupational stress, which eventually leads to exhaustion in working (Aghaei et al., 2013). Individuals with unhappy marriage may experience more stress than unmarried ones. Furthermore, a workload that is not in accordance with workers' ability can cause occupational stress. The lack of harmonious relationship between workers hinders communication and leads to frustration and occupational stress.

Effects of occupational stress at work appear on the workers' physique, psyche, and behavior. These workers cannot bear the stressors well, causing them to take day off and sudden leaves, increasing absenteeism rate. If no measure is taken, it will lead to various problems in the workplace, such as declining performance, work-related injury, and suicidal tendency.

PT PAL Indonesia (Persero) is a stateowned enterprise that runs shipyard industry. The main activities of this enterprise is producing warship and merchant ship and providing repair, maintenance, and general 
modification based on clients' specification. PT PAL Indonesia (Persero) mostly works on a project or a special requirement from clients. This means that the shipbuilding works are within specific deadlines. During this research, Merchant Ship Division of PT PAL Indonesia (Persero) was working on project of Landing Platform Dock (LPD) ship, which deadline was on December 2018.

Working in a deadline is very demanding for the workers. It leads to higher workloads because the workers have to complete the work within the predetermined time. Higher workloads, in turn, will trigger occupational stress. Moreover, higher workloads caused by tight deadlines in shipbuilding can lead to an increasing number of absenteeism and decreasing performance of the workers. These negative impacts will result in profit loss of the company.

The negative domino effect of occupational stress makes it necessary to be kept in check. Measurements need to be taken on occupational stress level and its contributing factors, such as work environment and individual characteristics. These measurements will be useful in formulating preventive and corrective measures to overcome stress at PT PAL Indonesia (Persero) and improve workers' performance.

The objective of the research is to examine occupational stress and its related factors in workers of Merchant Ship Division LPD project at PT PAL Indonesia (Persero). Specifically, the research aims to identify individual characteristic (age, education level, personality type, and marital status), work environment (workload and relationship at work), and occupational stress level experienced by the workers, and to identify the correlation between these variables in workers of Merchant Ship Division LPD at PT PAL Indonesia (Persero).

\section{METHODS}

This is an observational research in which data were obtained without any intervention or treatment towards subject. Based on the research design, this is a descriptive research since the researcher solely descripting any events or conditions that currently takes place.

Population in the research was all LPD project workers of Merchant Ship Division PT PAL Indonesia (Persero). No sampling was done, so data were obtained from all the 32 workers in the population.

The research was undertaken at Merchant Ship Division PT PAL Indonesia (Persero) located on Ujung, Semampir sub-district, Surabaya, East Java. Data collection was done during 31 July until 31 August 2018.

The variables accounted are as follow: independent variables including individual characteristics (age, education level, personality type, and marital status) and work environment (workload and relationship at work); and one dependent variable, which is occupational stress.

Data were collected using observation and questionnaire. Observation was done to learn the condition of the workplace and to measure physical workload of workers. Workload measurement was undertaken by observing workers activity, counting workers' calorie needs, and calculating average workload calculation based on SNI 13-7269-2009 regarding Work Load Assessment. Questionnaires used in this research were the Bortner personality questionnaire type, adapted from International Stress Management Association (ISMA) 2013, and questionnaire about relationship at work created by the researcher. This relationship questionnaire had been tested for validity and reliability with Alpha Cronbach coefficient point of 0.614.

Data obtained were then processed and analyzed descriptively. Results were then shown in a form of frequency table and cross tabulation. Furthermore, to identify correlation among variables and occupational stress, the researchers performed correlation test to find out the correlation coefficient and also chi test to obtain the contingency coefficient value.

\section{RESULT}

\section{Individual Characteristics}

Individual characteristics in this research include age, education level, personality type, and marital status.

Age

According to Table 1, it can be seen that $53.1 \%$ LPD project workers were $\geq 35$ years old. 
Table 1. Age Distribution of LPD Project Workers at Merchant Ship Division of PT PAL Indonesia (Persero) on August 2018

\begin{tabular}{lcc}
\hline \multicolumn{1}{c}{ Age } & N & \% \\
\hline$<35$ year old & 15 & 46.9 \\
$\geq 35$ year old & 17 & 53.1 \\
\hline Total & 32 & 100 \\
\hline
\end{tabular}

\section{Education Level}

Table 2. Education Level Distribution of LPD Project Workers at Merchant Ship Division of PT PAL Indonesia (Persero) on August 2018

\begin{tabular}{lcc}
\hline \multicolumn{1}{c}{ Education Level } & $\mathbf{N}$ & \% \\
\hline High School/equivalent & 28 & 87.5 \\
Diploma & 4 & 12.5 \\
\hline Total & 32 & 100 \\
\hline
\end{tabular}

The result shows that there was no worker with bachelor degree. Table 2 also shows that most $(87.5 \%)$ LPD project workers only went to high school or other equivalent institutions.

\section{Personality Type}

Based on Table 3, it can be seen that $56.2 \%$ LPD project workers had type A personality.

Table 3. Personality Type Distribution of LDP Project Workers at Merchant Ship Division of PT PAL Indonesia (Persero) on August 2018

\begin{tabular}{lcc}
\hline \multicolumn{1}{c}{ Personality Type } & N & \% \\
\hline Type A & 18 & 56.2 \\
Type B & 14 & 43.8 \\
\hline Total & 32 & 100 \\
\hline
\end{tabular}

\section{Marital Status}

Table 4. Marital Status Distribution of LPD Project Workers at Merchant Ship Division of PT PAL Indonesia (Persero) on August 2018

\begin{tabular}{lcc}
\hline \multicolumn{1}{c}{ Marital Status } & N & \% \\
\hline Married & 22 & 68.7 \\
Not Married & 10 & 31.3 \\
\hline Total & 32 & 100 \\
\hline
\end{tabular}

Table 4 shows that $68.7 \%$ LPD project workers were in a marriage during the data collection.

\section{Work Environment}

Work environment in this research includes workload and relationship at work.

\section{Workload}

Table 5. Workload Distribution of LDP Project Workers at Merchant Ship Division of PT PAL Indonesia (Persero) on August 2018

\begin{tabular}{lcc}
\hline \multicolumn{1}{c}{ Workload } & N & \% \\
\hline Light & 13 & 40.6 \\
Moderate & 19 & 59.4 \\
\hline Total & 32 & 100 \\
\hline
\end{tabular}

The calculation of calorie need of each worker and average workload shows no workers with heavy workload. Based on Table 5 , it can be seen that $59.4 \%$ LPD project workers had moderate workload.

\section{Relationship at Work}

Table 6. Relationship at Work Distribution of LDP Project Workers at Merchant Ship Division of PT PAL Indonesia (Persero) on August 2018

\begin{tabular}{lcc}
\hline \multicolumn{1}{c}{ Relationship at Work } & $\mathbf{N}$ & \% \\
\hline Good & 14 & 43.8 \\
Fair & 18 & 56.2 \\
\hline Total & 32 & 100 \\
\hline
\end{tabular}

Based on Table 6 , it can be seen that LPD project workers kept their relationship at work fairly well.

\section{Occupational Stress}

Table 7. Occupational Stress Distribution of LDP Project Workers at Merchant Ship Division of PT PAL Indonesia (Persero) on August 2018

\begin{tabular}{lcc}
\hline Occupational Stress & $\mathbf{N}$ & $\mathbf{\%}$ \\
\hline Mild & 7 & 21.8 \\
Moderate & 22 & 68.8 \\
Severe & 3 & 9.4 \\
\hline Total & 32 & 100 \\
\hline
\end{tabular}


Based on Table 7, it can be seen that $68.8 \%$ LPD project workers suffered moderate stress.

\section{Correlation between Individual Characteristic and Occupational Stress}

\section{Correlation between Age and Occupational Stress}

Based on Table 8, it can be seen that of the workers who were $\geq 35$ years old, $82.4 \%$ suffered moderate stress and $5.9 \%$ suffered severe stress. Spearman correlation test result shows a correlation coefficient value of 0.146 .

\section{Correlation between Education Level and Occupational Stress}

Based on Table 8 , it can be seen that among workers with high school education level or equivalent, $75 \%$ suffered moderate stress and $10.7 \%$ suffered severe stress. Spearman correlation test yields a correlation coefficient value of -0.446 .

\section{Correlation between Personality Type and Occupational Stress}

Based on Table 8, it can be seen that among workers workers with type A personality, $55.5 \%$ suffered moderate stress and $16.7 \%$ suffered severe stress. Chi square test result shows a contingency coefficient value of 0.334 .

\section{Correlation between Marital Status and Occupational Stress}

Based on Table 8 , it can be seen that of the married workers, $68.2 \%$ suffered moderate stress and $13.6 \%$ suffered severe stress. Chi square test result shows a contingency coefficient value of 0.231 .

\section{Correlation between Work Environment and Occupational Stress}

\section{Correlation between Workload and Occupational Stress}

Based on Table 8 , it can be seen that among workers with moderate workload, $89.5 \%$ suffered moderate stress and $10.5 \%$ suffered severe stress. Spearman correlation test result shows a correlation coefficient value of 0.533 .

\section{Correlation between Relationship at Work and Occupational Stress}

Based on Table 8, it can be seen that of the workers with fair relationship, $77.8 \%$ suffered moderate stress and $16.7 \%$ suffered severe stress. Spearman correlation test yields a coefficient correlation value of 0.494 .

\section{DISCUSSION}

\section{Corelation between Individual Characteristic and Occupational Stress}

\section{Correlation between Age Factor and Occupational Stress}

Seventeen out of 32 LPD project workers at Merchant Ship Division were $\geq 35$ years old during the data collection $(53.1 \%)$. Age correlates with the emergence of occupational stress. According to Irkhami (2015), a person will more likely be prone to stress on ages between 21-40 and 40-60.

Based on Table 8 , it can be seen that workers who are $\geq 35$ years old mostly suffered moderate stress (14 workers) and only one suffered severe stress. The $\geq 35$ year-old workers who suffered stress were affected by high work demands and the inability of their body to keep up with those demands. This finding is in line with Panengah's (2012), which states that above 40 years old, physical ability of the body decreases about 30-50\%. Aging negatively influences body performances such as visual ability, thinking process, memorizing ability, and hearing ability. All of which make an individual becomes more prone to stress.

Spearman correlation test result shows correlation coefficient value of 0.146 . It indicates weak relation between age and occupational stress. Moreover, positive correlation coefficient value also indicates there is a linear correlation, so that it can be concluded that the older the workers are, the higher the risk of occupational stress. This result is similar to Karima's research (2014) which states that an increase in age increases the stress level of workers. 
Table 8. Cross Tabulation between Individual Characteristic Factor and Work Environment Factor with Occupational Stress of Project LPD Workers at Merchant Ship Division PT PAL Indonesia (Persero) on August 2018.

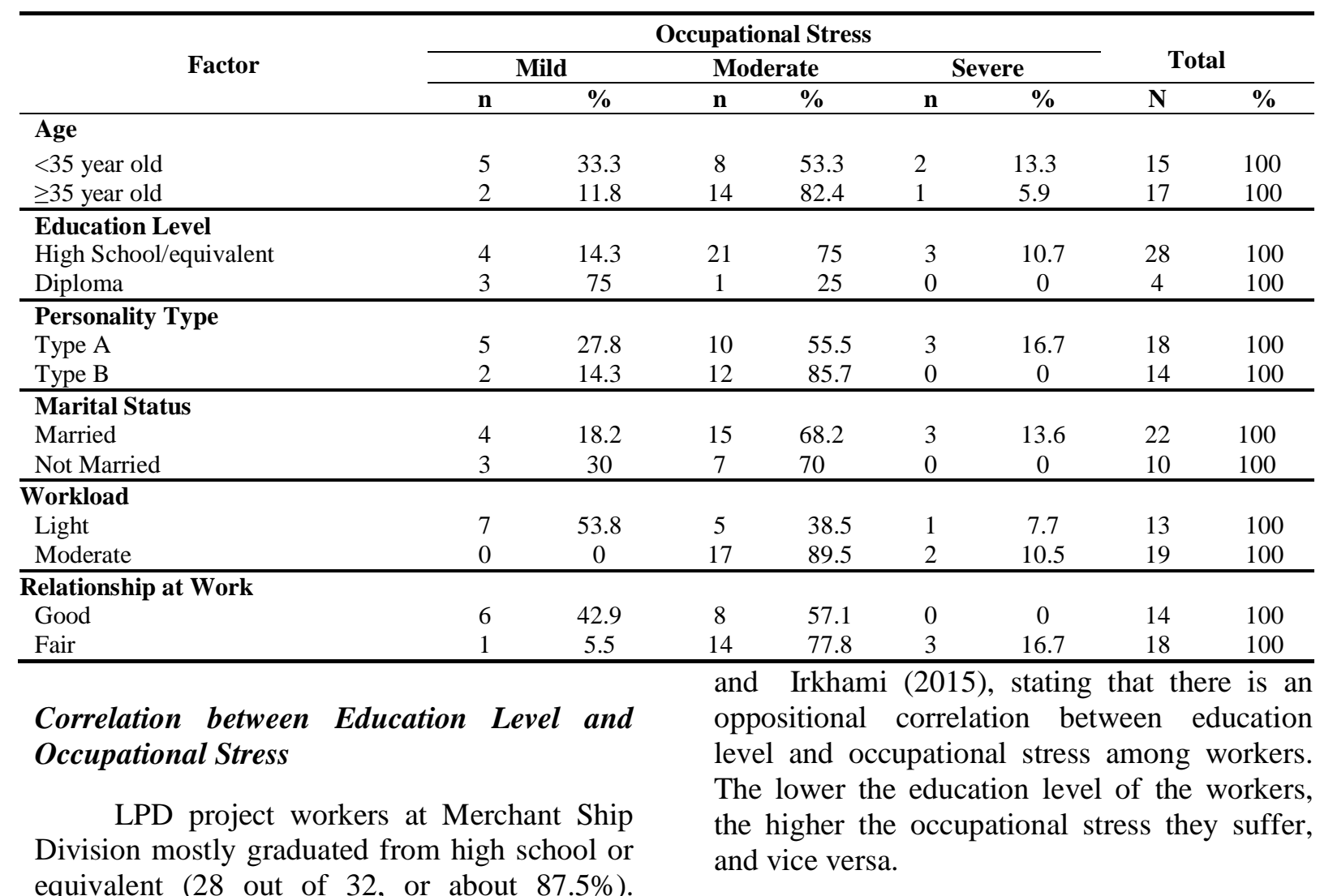

Education level commonly becomes an important consideration in recruitment process in a company. Moreover, education level also influences an individual's way of thinking and behavior.

Based on Table 8 , it can be seen that high-school-graduated workers mostly suffered moderate stress (21 out of 32). Spearman correlation test result shows a correlation coefficient value of -0.446 . This means that there is a moderate correlation between education level and occupational stress. Furthermore, negative correlation coefficient value means that the correlation between education level and occupational stress works in opposite direction. This means that the lower the education level of workers, the more severe the occupational stress they suffer, and vice versa.

This negative correlation between education level and occupational stress occurs because lower education level results in lesser skills. Inadequate skills lead to difficulties in finishing work, which then triggers occupational stress. This condition is supported by researches conducted by Candraditya (2016)

\section{Correlation between Personality Type and Occupational Stress}

The majority of LPD project workers had type A personality (18 out of 32 , or $56.3 \%$ ). Type A individuals tend to be competitive, ambitious, impatient, aggressive, and more prone to stress. On the contrary, type B individuals tend to be patient, having low temperament, and easy going. These traits make people with type B personality more immune to stress.

Based on Table 8 , it can be seen that workers with type A personality suffered moderate stress (10 individuals) and severe stress (3 individuals). It can be concluded that workers with type A personality were more prone to higher occupational stress. This result is in line with Pestonjee \& Pandey (2013) who states that type A personality can trigger the emergence of high occupational stress, especially when control over work is weak. However, the contingency coefficient value of 0.334 from the Chi square test shows that actually there is only a weak correlation 
between personality type and occupational stress.

\section{Correlation between Marital Status Factor and Occupational Stress}

The majority (22 individuals, or $68.7 \%$ ) of LPD project were in a marriage. Being married brings positive impacts to a person if the marriage itself is going well. On the contrary, if the marriage is not going well, there will be negative impacts.

Based on Table 8 , it is clear that most $(15$ out of 32) married workers suffered moderate stress, while only three suffered severe stress. It can be concluded that married workers suffered higher occupational stress. Chi square test shows a contingency coefficient value of 0.231 . This value means there is weak correlation between marital status and occupational stress.

Marital status can affect an individual's stress level. In the case of working individuals, problem in marriage leads to susceptibility to occupational stress. This finding parallels to Ogden (2012), in a way that marriage is a global parameter to predict happiness. Therefore, it can be concluded that unhappy marriage can lead to higher occupational stress, as compared to of those who were single.

\section{Correlation between Work Environment and Occupational Stress}

\section{Correlation between Workload and Occupational Stress}

More than half of LPD project workers (18 out of 32 ) had moderate workload. It can be seen on Table 8 that workers with moderate workload suffered moderate stress (17 individuals), and two others suffered severe stress. Spearman correlation test shows a correlation coefficient value of 0.533 . This value shows that there is a moderate correlation between workload and occupational stress. Positive correlation coefficient value means that there is a parallel correlation: the heavier the workload, the higher the occupational stress suffered.

Working in LPD project requires good concentration and high physical endurance since completion demands workers to perform various everchanging position: sitting, standing, squatting, and bending over. Workers have to constantly move from one position to another for a long time. Furthermore, most of the works are performed in a constricted area with less ventilation, causing temperature increase.

Physically demanding body position, along with long period of time and high temperature, results in a heavy physical workload. This condition, in turn, leads to occupational stress. This is also in line with Manuaba (2000) who states that excessive workload can lead to occupational stress. When the body takes excessive load, it suffers exhaustion, both physically and mentally, triggering other reactions such as headache, digestion problems, and emotional instability. These reactions will also lead to occupational stress.

\section{Correlation between Relationship at Work and Occupational Stress}

More than half (18 individuals, or 56.3\%) of LPD project workers at Merchant Ship Division maintained fairly good relationship. Relationship at work, either with co-workers or with bosses, can be a defining factor of occupational stress. According to Table 8, it can be seen that as much as 14 workers who had fair quality relationship at work suffered moderate stress. The other three even suffered severe stress. Spearman correlation test shows a correlation coefficient value of 0.494 . It means that there is a moderate correlation between relationship at work and occupational stress. Correlation coefficient value which shows positive number represents a parallel correlation: the lower the quality of relationship at work, the higher the occupational stress suffered by the workers.

Good relationship with co-workers and bosses can be a motivation for workers to perform their job well, which in turn will minimize pshychological pressure and occupational stress. On the contrary, if the relationship at work is of less quality, it can cause stress. This assertion is supported by Munandar (2001), saying that when relationship among co-workers is interrupted, it will increase pshychological tension, negatively affect physical condition, and create a feeling of being threatened by the boss or other workers.

\section{CONCLUSION}

The majority (68.8\%) of workers suffered moderate stress. As much as $53.1 \%$ 
were $\geq 35$ year old, $87.5 \%$ only had high school education or something equivalent, $56.2 \%$ had type A personality, $68.7 \%$ were married, $59.4 \%$ took moderate workload, and $56.2 \%$ of workers had fair quality relationship at work. Factors which have major role in contributing to occupational stress are education level, workload, and relationship at work, since these three are moderately correlated with occupational stress. Other factors such as age, personality type, and marital status have less influence on occupational stress since they are weakly correlated with occupational stress.

\section{ACKNOWLEDGEMENT}

The researchers would like to express their gratitude and appreciation to Sho'im Hidayat, dr., M.Sc., for the valuable instructions, corrections, and suggestions for the completion of this research. Gratitude and appreciation also go to Mr. Lilik Budiono, Mr. Andika, and Mr. Indita as part of HSE at the Merchant Ship Division PT PAL Indonesia (Persero) for their assistance throughout the course of this research.

\section{REFERENCES}

Aghaei, M. et al. (2013) 'The Relation between Personality Type, Locus of Control, Occupational Satisfaction and Occupational Exhaustion and Determining the Effectiveness of Stress Inoculation Training (SIT) on Reducing it among staffers of Saipa Company', Research Journal of Recent Sciences, 2(2), pp. 6-11.

Candraditya, R. (2016) The Relationship between Noise Levels and Job Stress in Workers at PT Vale Indonesia. Undergraduate Thesis. Surabaya: Faculty of Public Health Universitas Airlangga.

Failasufa, I., Pawenang, E. T. and Indarjo, S. (2014) 'The Relationship between Noise and Heat Pressure with Job Stress in Spinning Section Workers', Unnes Journal of Public Health, 3(4), pp. 1-8.

Health and Safety Executive (2017) Workrelated Stress, Depression, or Anxiety Statistics in Great Britain 2017, United Kingdom: Health and Safety Executive.

Irkhami, F. L. (2015) 'Factor Associated with Job Stress in Divers at PT X.', The Indonesian Journal of Occupational
Safety and Health, 4(1), pp. 54-63.

Karima, A. (2014) Factors Associated with Job Stress in Workers at PT X In 2014. Undergraduate Thesis. Jakarta: Faculty of Medicine anda Health Science Universitas Islam Negeri Syarif Hidayatullah.

Manuaba, A. (2000) Relationship between Workload and Work Capacity. Jakarta: Rineka Cipta.

Munandar, A. S. (2001) Industrial and Organizational Psychology. Jakarta: Universitas Indonesia Press.

Ogden, J. (2012) Health Psychology. New York: McGraw Hill.

Panengah, Y. I. (2012) The Relationship between Workload and Job Stress for Workers in Wirun Gamelan Industrial Center Sukoharjo. Undergraduate Thesis. Surakarta: Faculty of Medicine Universitas Sebelas Maret.

Pestonjee, D. and Pandey, S. (2013) Stress and Work: Perspective in Understanding and Managing Stress. India: India: Sage Publishing.

Wijono, S. (2012) Industrial and Organizational Psychology. Revision. Jakarta: Prenada Media Group. 